\title{
"Ethnic density of neighbourhood at age 15 modifies the risk for psychosis". So what?
}

Citation for published version (APA):

Selten, J-P., \& Termorshuizen, F. (2017). "Ethnic density of neighbourhood at age 15 modifies the risk for psychosis". So what? Schizophrenia Research, 190, 88-89. https://doi.org/10.1016/j.schres.2017.11.002

Document status and date:

Published: 01/12/2017

DOI:

10.1016/j.schres.2017.11.002

Document Version:

Publisher's PDF, also known as Version of record

Document license:

Taverne

Please check the document version of this publication:

- A submitted manuscript is the version of the article upon submission and before peer-review. There can be important differences between the submitted version and the official published version of record.

People interested in the research are advised to contact the author for the final version of the publication, or visit the DOI to the publisher's website.

- The final author version and the galley proof are versions of the publication after peer review.

- The final published version features the final layout of the paper including the volume, issue and page numbers.

Link to publication

\footnotetext{
General rights rights.

- You may freely distribute the URL identifying the publication in the public portal. please follow below link for the End User Agreement:

www.umlib.nl/taverne-license

Take down policy

If you believe that this document breaches copyright please contact us at:

repository@maastrichtuniversity.nl

providing details and we will investigate your claim.
}

Copyright and moral rights for the publications made accessible in the public portal are retained by the authors and/or other copyright owners and it is a condition of accessing publications that users recognise and abide by the legal requirements associated with these

- Users may download and print one copy of any publication from the public portal for the purpose of private study or research.

- You may not further distribute the material or use it for any profit-making activity or commercial gain

If the publication is distributed under the terms of Article $25 \mathrm{fa}$ of the Dutch Copyright Act, indicated by the "Taverne" license above, 


\title{
"Ethnic density of neighbourhood at age 15 modifies the risk for psychosis". So what?
}

\author{
Jean-Paul Selten ${ }^{\mathrm{a}, \mathrm{b}, *}$, Fabian Termorshuizen ${ }^{\mathrm{b}}$ \\ a School for Mental Health and Neuroscience, University of Maastricht, Maastricht, The Netherlands \\ ${ }^{\mathrm{b}}$ Rivierduinen, Institute for Mental Health, Leiden, The Netherlands
}

\section{A R T I C L E I N F O}

\section{Article history:}

Received 31 October 2017

Accepted 1 November 2017

Available online 10 November 2017

\section{Keywords:}

Schizophrenia

Epidemiology

Migration

Ethnic minority

Ethnic density

Social exclusion

An interesting paper in this journal reports that the risk for teenagers from ethnic minority groups to develop non-affective psychotic disorder in adult life depends on the size of their group in their neighbourhood of residence (Schofield et al., 2017a). According to a second paper from the same group of authors, this effect is prominent in the second generation and weak or absent in the first generation (Schofield et al., 2017b).

Since research into the role of social factors in the aetiology of psychosis seems to have vanished from mainstream research in NorthAmerica, we sometimes wonder what American colleagues might think about such findings from Europe. Things were markedly different in the 20th century, when there was a rich American literature on the social background of psychosis. Malzberg (1964a), for instance, epidemiologist in New York, provided one of the first descriptions of the ethnic density effect by showing that the annual first admission rates for dementia praecox in Quebec, 1949-1952, standardized for age and sex, were 2.3 times higher for the Canadians of British origin than for those of French origin. In Ontario, in contrast, such rates were 1.2 times higher for the Canadians of French origin. Malzberg also demonstrated that the rates for the British were higher in Quebec than in Ontario and that the opposite was true for the French. He concluded: "It

\footnotetext{
* Corresponding author at: GGZ Rivierduinen, Sandifortdreef 19, 2333 ZZ Leiden, The Netherlands.

E-mail address: j.selten@rivierduinen.nl (J.-P. Selten).
}

is clear, therefore, that the incidence of mental disease is affected by the minority or majority status of a population" (p. 70).

While subsequent studies could not demonstrate convincingly a similar effect on the risk for depression or anxiety, the effect on the risk for psychotic disorder turned out to be a highly replicable finding (Shaw et al., 2012). However, since the exposure in the latter studies was usually determined around the time of diagnosis, the possibility remained that individuals with a genetic predisposition for psychosis moved to low ethnic density areas before the onset of disorder.

A great merit of the papers by Schofield and colleagues is that they eliminate this possibility. Using Danish registries they created a cohort of more than 2 million people, born in 1965 or later, and examined whether neighbourhood exposures at age 15 influenced the risk of developing non-affective psychotic disorder. The results were unambiguous and showed that the incidence for all ethnic minority groups was greater for individuals who had grown up in low ethnic density neighbourhoods. Obviously, these findings are not only important for psychiatrists and psychologists, but also for politicians, because several countries worldwide have to provide accommodation for millions of refugees.

Another merit of the Schofield et al. studies is the computation of the ethnic density effect within a particular ethnic minority group: for instance, the comparison of risks for Africans in low and high ethnic density neighbourhoods. A comparison of migrants to natives within the same neighbourhoods would have been problematic, because during the prodromal phase of the illness many native individuals move to poor areas with many migrants (Termorshuizen et al., 2014). The much stronger effect of ethnic density in the second generation than in the first is perhaps not so surprising, because many foreign-born individuals who live in Denmark at age 15 may have arrived a few years earlier and have not spent many years in the pertinent neighbourhood.

There are at least two lines of interpretation for these findings: (i) the stress of a minority position is a psychosis risk factor and this type of stress is buffered by ethnic density; (ii) parents who carry many psychosis genes prefer to live in low ethnic density neighbourhoods.

The first hypothesis is supported by several studies, one of which suggested that ethnic density buffers psychosocial adversity, because people in areas of lower own-group density report greater social adversity that is in turn associated with reporting more psychotic experiences (Das-Munshi et al., 2012). According to this view, minority status may generate negative emotions which are relevant for the aetiology of psychosis. 
The second interpretation is supported by the fact that schizophrenia is more likely to develop upon the background of a schizoid or introvert personality. Is it not possible, then, that parents with such a personality withdraw themselves from social life and prefer a residence in a low ethnic density neighbourhood? This interpretation meets with at least two difficulties. First, Schofield et al. adjusted the results for a record of a psychiatric disorder in either parent, which is meaningful because the threshold for psychiatric care in Denmark is low. Still, one could argue that this adjustment is imperfect, because many schizoid or introvert individuals may not seek contact with psychiatric facilities. A second problem, however, is the limited freedom of choice. Although the authors do not provide information on this topic, few migrants from developing countries will have the resources to choose a particular neighbourhood. It is much more likely that a particular accommodation is assigned to them. This was also true for Camberwell, London, where the reported ethnic density effect could not be due to selection bias, because most housing in Camberwell was local authority (public) housing (Boydell et al., 2001). Although we believe that the evidence for the first interpretation is stronger than that for the second, it would be useful if we could definitively exclude the second possibility.

As for the interpretation of their findings, Schofield and colleagues state that the generational differences in the magnitude of the ethnic density effect point to different causal processes behind the increased risk of psychosis among migrants. For the first generation they assume that the stressful experience of migration plays a major role (and, in the case of refugees, that of trauma), while the stress of acculturation is more important for the second.

We are of a somewhat different opinion, because these considerations are difficult to reconcile with Occam's principle of parsimony. If one considers the ethnic density effect in combination with other results obtained in Europe, such as the high rates for migrants from developing countries and for those with a black skin colour, it is more likely that difficulties entering society is a common denominator. This ties in with epidemiological findings on other groups with similar difficulties, such as homosexuals, individuals with hearing impairment, a low IQ or an autism spectrum disorder (Selten et al., 2016).

An interpretation along such lines is also supported by some apparent exceptions to the rule. Examples are the low rates for Swedes in Finland, who are economically successful and have lower divorce rates than the Finns (Suvisaari et al., 2014), the low rates for the Hutterites, a religious minority known for its economic success and social cohesion (Nimgaonkar et al., 2000), the higher risks for Maori's than for migrants in New Zealand (Tapsell et al., 2017) and the relatively low risk for migrants to Israel, whose migration involves a change from exclusion to inclusion (Corcoran et al., 2009).

Some readers may wonder what became of the selection hypothesis, which posited that the increased risk for migrants is due to selective migration of individuals who are genetically at risk for psychosis (Ødegaard, 1932). Although a substantial number of studies tested the hypothesis and obtained negative results (for review, see van der Ven et al., 2015), we believe that there may be a role for selection, but in a way opposite to the one intended by Ødegaard. We think it is likely that positive selection contributes to the low risk in Canada and, perhaps, the USA. With a few exceptions (an increased risk for migrants from the Caribbean and Bermuda), the risk for migrants to Canada seems to be lower than that for the Canadian-born (Anderson et al., 2015). This may be the result of a process of self-selection and of a selection imposed by the government, because Canada's point system favours individuals with host language proficiency, higher education, and work experience. The last study on this topic from the USA dates from 1964 (Malzberg, 1964b).
Finally, it is worthwhile to note that some core questions in this area remain unanswered. Why is the effect of migration or ethnic density greater and more consistent for psychosis than for depression (Shaw et al., 2012; Mindlis and Boffetta, 2017)? For which ethnic groups is the effect of ethnic density stronger? For which outcome (psychosis, depression, suicide)? Which are the underlying mechanisms? More research is needed, in the USA as well as in Europe.

\section{Contributors}

Jean-Paul Selten drafted the manuscript.

Fabian Termorshuizen provided a critical revision of the manuscript for important intellectual content.

\section{Role of the funding source}

No funding source.

\section{Conflict of interest}

The authors report no conflict of interest.

\section{Acknowledgment}

No acknowledgment.

\section{References}

Anderson, K., Cheng, J., Susser, E.S., McKenzie, K.J., Kurdyak, P., 2015. Incidence of psychotic disorders among first-generation immigrants and refugees in Ontario. CMAJ 187, E279-286.

Boydell, J., van Os, J., McKenzie, K., Allardyce, J., Goel, R., McCreadie, R.G., Murray, R.M., 2001. Incidence of schizophrenia in ethnic minorities in London: ecological study into interactions with environment. BMJ 323, 1336-1338.

Corcoran, C., Perrin, M., Harlap, S., Deutsch, L., Fennig, S., Manor, O., Nahon, D., Kimhy, D., Malaspina, D., Susser, E.S., 2009. Incidence of schizophrenia among second-generation immigrants in the Jerusalem perinatal cohort. Schizophr. Bull. 35, 596-602.

Das-Munshi, J., Becares, L., Boydell, J., Dewey, M., Morgan, C., Stansfeld, S., Prince, M.J., 2012. Ethnic density as a buffer from psychotic experiences: findings from a national survey (EMPIRIC). Br. J. Psychiatry 201, 282-290.

Malzberg, B., 1964a. Mental Disease in Canada, 1950-1952. A Study of Comparative Incidence of Mental Disease Among Those of British and French Origin. Research Foundation for Mental Hygiene, Albany, New York.

Malzberg, B., 1964b. Mental disease among native- and foreign-born whites in New York State, 1949-1951. Ment. Hyg. 48, 478-499.

Mindlis, J., Boffetta, P., 2017. Mood disorders in first- and second-generation immigrants: systematic review and meta-analysis. Br. J. Psychiatry 210, 182-189.

Nimgaonkar, V.L., Fujiwara, T.M., Dutta, M., Wood, J., Gentry, K., Maendel, S., Morgan, K., Eaton, J., 2000. Low prevalence of psychoses among the Hutterites, an isolated religious community. Am. J. Psychiatry 157 (2000), 1065-1070.

Ødegaard, Ø., 1932. Emigration and insanity. Acta Psychiatr. Neurol. Scand. 38, 79-107.

Schofield, P., Thygesen, M., Das-Munshi, J., Becares, L., Cantor-Graae, E., Agerbo, E., Pedersen, C., 2017a. Neighbourhood ethnic density and psychosis. Is there a difference according to generation? Schizophr. Res. (In press).

Schofield, P., Thygesen, M., Das-Munshi, J., Becares, L., Cantor-Graae, E., Pedersen, C., Agerbo, E., 2017b. Ethnic density, urbanicity and psychosis risk for migrant groups. A population-base cohort study. Schizophr. Res. (in press).

Selten, J.P., van Os, J., Cantor-Graae, E., 2016. The social defeat hypothesis of schizophrenia: issues of measurement and reverse causality. World Psychiatry 15, 294-295.

Shaw, R.J., Atkin, K., Becares, L., Albor, C.B., Stafford, M., Kiernan, K., Nazroo, J.Y., Wilkinson, R.G., Pickett, K.E., 2012. Impact of ethnic density on adult mental health disorders: narrative review. Br. J. Psychiatry 201, 11-19.

Suvisaari, J., Opler, M., Lindbohm, M.L., Sallmen, M., 2014. Risk of schizophrenia and minority status: a comparison of the Swedish-speaking minority and the Finnish-speaking majority in Finland. Schizophr. Res. 159, 303-308.

Tapsell, R., Hallett, C., Mellsop, G., 2017. The rate of mental health service use in New Zealand as analysed by ethnicity. Australas. Psychiatry https://doi.org/10.1177/ 1039856217715989 ePub ahead of print.

Termorshuizen, F., Smeets, H.M., Braam, A.W., Veling, W., 2014. Neighbourhood ethnic density and psychotic disorders among ethnic minority groups in Utrecht City. Soc. Psychiatry Psychiatr. Epidemiol. 49, 1093-1102.

van der Ven, E., Dalman, C., Wicks, S., Allebeck, P., Magnusson, C., van Os, J., Selten, J.P., 2015. Testing Ødegaard's selective migration hypothesis: a longitudinal cohort study of risk factors for non-affective psychotic disorders among prospective migrants. Psychol. Med. 45, 727-734. 